\title{
Relation between coronary artery size and left ventricular wall mass ${ }^{1}$
}

\author{
B. S. Lewis and M. S. Gotsman \\ From the Cardiac Unit, Wentworth Hospital and the University of Natal, Durban, South Africa
}

The cross-sectional area of the lumen of the proximal right coronary artery and the main stem of the left coronary artery were measured in 27 patients -6 normal subjects, 8 with minor coronary artery disease, 8 with aortic incompetence, 3 with primary myocardial disease, and 2 with a prolapsing posterior leaflet of the mitral valve and mild mitral incompetence.

There was close linear correlation between left ventricular wall mass and the cross-sectional area of the main stem of the left coronary artery, of the proximal right coronary artery, and the sum of the two.

Increase in cross-sectional area was related to the increase in muscle mass, and it is suggested that, if velocity of coronary artery blood flow is constant, dilatation of the proximal coronary arteries facilitates coronary flow appropriate to the degree of left ventricular hypertrophy.

Although there are many determinants of coronary blood flow, several studies suggest that blood flow per unit of muscle mass is remarkably constant (Ross et al., 1964; Gorlin et al., 1964; Rowe et al., I965; Frank, Levinson, and Hellems, 1965; Brink and Lewis, 1967; Holmberg et al., 1967).

We have been impressed by the size of the coronary arteries in patients with left ventricular hypertrophy and have measured the size of the proximal left and right coronary arteries to see whether size can be measured in life (MacAlpin et al., 1972) and whether it is related to the change in left ventricular wall mass.

\section{Patients}

An unselected miscellaneous group of 27 patients in whom there was a clinical indication for coronary ateriography was studied: 6 were found to have a normal heart, 8 had minor coronary artery disease but without important asynergy of the anterolateral surface of the left ventricle, $8 \mathrm{had}$ aortic incompetence, $3 \mathrm{had}$ primary myocardial disease, and 2 had mitral incompetence due to a prolapsing posterior cusp. No patient had important pulmonary hypertension. The clinical and haemodynamic details which relate to these patients are summarized in Table $\mathrm{r}$. The patients had important chest pain resembling angina pectoris and they were Received I6 April, I973.

1 Supported by grants from the Medical Research Council, and Anglo American Corporation of South Africa and the Chris Barnard Fund. part of a study of 3,000 patients submitted to cardiac catheterization in a period of 5 years: 400 of these patients had important coronary artery disease.

\section{Methods}

Routine right and left heart catheterization was performed using the mid-chest level as the zero reference for pressures. Cardiac output was measured by the direct Fick principle. Left ventriculograms were made in the right anterior oblique position using slow injections of $50 \mathrm{ml}$ of 76 per cent Urografin and a Philips 9 in.-image intensifier with a cine technique. Ventricular volumes were measured using the single plane angiogram (Greene et al., r967) and left ventricular wall mass was calculated assuming uniform wall thickness at end-diastole (Kennedy, Trenholme, and Kasser, I970). The patients were in sinus rhythm during ventriculography.

Selective coronary arteriograms were made using the Judkins method (1967) in multiple oblique views with a cine technique on a 6 in.-image intensifier (Gotsman et al., 1969, 1973). The diameter of the proximal right and main stem left coronary arteries was measured in profile in the position in which this profile was best seen. The stem of the catheter was used as the reference standard for magnification (Rees, 1972). The luminal cross-sectional area of each main stem artery was calculated from the measurements of coronary artery diameter. The error in measuring coronary artery size may be up to $0.5 \mathrm{~mm}$, or Io per cent of the diameter of a small artery. This can produce an error in cross-sectional area of 20 per cent. Vessel size was measured in duplicate where there was any doubt about size and only films which were of high quality were used for analysis. 
TABLE I The patients

\begin{tabular}{|c|c|c|c|c|c|c|c|c|}
\hline & \multirow{2}{*}{$\begin{array}{l}\text { No. of } \\
\text { patients }\end{array}$} & \multirow{2}{*}{$\begin{array}{l}\text { Age } \\
(y r)\end{array}$} & \multirow{2}{*}{$\begin{array}{l}\text { Cardiac index } \\
\left(m l / \min \text { per } m^{2}\right)\end{array}$} & \multirow{2}{*}{$\begin{array}{l}\text { Stroke index } \\
\left(m l / \text { beat per } m^{2}\right)\end{array}$} & \multicolumn{2}{|c|}{$L V$ pressure $(\mathrm{mmHg})$} & \multirow{2}{*}{$\begin{array}{l}\text { Peak } \\
L V p / d t \\
(\mathrm{mmHg} / \mathrm{sec})\end{array}$} & \multirow{2}{*}{$\begin{array}{l}L V \text { ejection } \\
\text { fraction } \\
(\%)\end{array}$} \\
\hline & & & & & Systolic & $\begin{array}{l}\text { End- } \\
\text { diastolic }\end{array}$ & & \\
\hline Normal & 6 & $\begin{array}{l}31 \\
(17-39)\end{array}$ & $\begin{array}{l}4 \cdot 1 \\
(3 \cdot 3-4 \cdot 9)\end{array}$ & $\begin{array}{l}56 \\
(37-72)\end{array}$ & $\begin{array}{l}\text { II2 } \\
(95-130)\end{array}$ & $\begin{array}{l}9 \\
(5-12)\end{array}$ & $\begin{array}{l}1681 \\
(1449-1872)\end{array}$ & $\begin{array}{l}70 \\
(59-83)\end{array}$ \\
\hline $\begin{array}{l}\text { Coronary artery } \\
\text { disease }\end{array}$ & 8 & $\begin{array}{l}47 \\
(38-58)\end{array}$ & - & - & $\begin{array}{l}\text { II3 } \\
(88-130)\end{array}$ & $\begin{array}{l}\text { II } \\
(5-22)\end{array}$ & $\begin{array}{l}1436 \\
(1057-1932)\end{array}$ & $\begin{array}{l}72 \\
(54-85)\end{array}$ \\
\hline $\begin{array}{l}\text { Aortic } \\
\quad \text { incompetence }\end{array}$ & & $\begin{array}{l}43 \\
(19-66)\end{array}$ & $\begin{array}{l}3 \cdot 7 \\
(2 \cdot 5-7 \cdot 2)\end{array}$ & $\begin{array}{l}52 \\
(4 I-96)\end{array}$ & $\begin{array}{l}143 \\
(120-182)\end{array}$ & $\begin{array}{l}19 \\
(12-36)\end{array}$ & $\begin{array}{l}\text { I503 } \\
\text { (II47-2II4) }\end{array}$ & $\begin{array}{l}60 \\
(46-80)\end{array}$ \\
\hline \multicolumn{9}{|l|}{ Primary } \\
\hline $\begin{array}{l}\text { myocardial } \\
\text { disease }\end{array}$ & 3 & $\begin{array}{l}53 \\
(49-59)\end{array}$ & $\begin{array}{l}2 \cdot 7 \\
(1 \cdot 2-3 \cdot 7)\end{array}$ & $\begin{array}{l}29 \\
(I I-49)\end{array}$ & $\begin{array}{l}137 \\
(105-190)\end{array}$ & $\begin{array}{l}18 \\
(12-22)\end{array}$ & $\begin{array}{l}917 \\
(670-1057)\end{array}$ & $\begin{array}{l}32 \\
(19-52)\end{array}$ \\
\hline $\begin{array}{l}\text { Mitral } \\
\text { incompetence }\end{array}$ & 2 & $\begin{array}{l}16 \\
(12-20)\end{array}$ & $\begin{array}{l}4 \cdot 1 \\
(3 \cdot 6-4 \cdot 6)\end{array}$ & $\begin{array}{l}54 \\
\left(4^{8}-59\right)\end{array}$ & $\begin{array}{l}\text { I0I } \\
(99-103)\end{array}$ & $\begin{array}{l}12 \\
\text { (IO-I4) }\end{array}$ & $\begin{array}{l}1250 \\
(1082-1419)\end{array}$ & $\begin{array}{l}73 \\
(70-75)\end{array}$ \\
\hline
\end{tabular}

Note: Mean values are given with range in brackets.

TABLE 2 Coronary artery size

\begin{tabular}{|c|c|c|c|}
\hline & \multicolumn{3}{|c|}{ Cross-sectional area of coronary arteries $\left(\mathrm{mm}^{2} / \mathrm{m}^{2}\right)$} \\
\hline & $\begin{array}{l}\text { Left coronary } \\
\text { artery }\end{array}$ & $\begin{array}{l}\text { Right coronary } \\
\text { artery }\end{array}$ & $\begin{array}{l}\text { Total } \\
\text { left coronary } \\
\text { + right } \\
\text { coronary }\end{array}$ \\
\hline $\begin{array}{l}\text { Normal } \\
\text { Coronary artery disease } \\
\text { Aortic incompetence } \\
\text { Primary myocardial disease } \\
\text { Mitral incompetence }\end{array}$ & $\begin{array}{l}9 \cdot 6 \pm 4 \cdot 5 \\
8 \cdot 8 \pm 2 \cdot 3 \\
23 \cdot 8 \pm 8 \cdot 2 \\
14 \cdot 9 \pm 2 \cdot 3 \\
11 \cdot 9\end{array}$ & $\begin{array}{l}8 \cdot 5 \pm 1 \cdot 8 \\
8 \cdot 9 \pm 2 \cdot 5 \\
12 \cdot 6 \pm 4 \cdot 7 \\
10 \cdot 1 \pm 3 \cdot 0 \\
6 \cdot 1\end{array}$ & $\begin{array}{l}18 \cdot 0 \pm 5 \cdot 1 \\
17 \cdot 6 \pm 3 \cdot 3 \\
36 \cdot 4 \pm 12 \cdot 1 \\
25 \cdot 0 \pm 5 \cdot 0 \\
18 \cdot 0\end{array}$ \\
\hline
\end{tabular}

Note: Mean values $\pm \mathrm{I}$ standard deviation are shown.

The correlations were analysed by standard statistical methods on a Wang $700 \mathrm{C}$ programmable calculator with plotter-printer output.

\section{Results}

The results are summarized in Table 2 and shown in detail with the statistical analysis in Fig. I to 3. In normal subjects the cross-sectional area of the right coronary artery was $8.5 \pm \mathrm{r} .8 \mathrm{~mm}^{2} / \mathrm{m}^{2}$, of the left coronary artery $9.6 \pm 4.5 \mathrm{~mm}^{2} / \mathrm{m}^{2}$, and the total was $18 \cdot 0 \pm 5 \cdot 1 \mathrm{~mm}^{2} / \mathrm{m}^{2}$. The total cross-sectional area of the right and left coronary arteries and the sum of the two was related to left ventricular wall mass (Fig. I-3). A greater correlation was observed between left ventricular wall mass and total crosssectional area $(r=0.84)$ than left coronary artery $(r=0.82)$ or right coronary artery $(r=0.68)$.

\section{Comments and discussion}

Left ventricular wall stress appears to be a determinant of left ventricular muscle mass and, in general, compensatory hypertrophy is appropriate to the abnormality in wall stress (Rackley et al., 1970; Hood, I97I). Though, under resting conditions, myocardial oxygen consumption and coronary blood flow are determined by many different factors, blood flow remains constant per unit of muscle mass in the presence of ventricular hypertrophy (Sarnoff et al., 1958; Ross et al., 1964; Britman and Levine, 1964; Gorlin et al., I964; Rowe et al., 1965; Brink and Lewis, 1967; Holmberg et al., 1967; Coleman, 197I; Braunwald, 197I; Sonnenblick and Skelton, 1971). If one assumes that the velocity of blood flow in the major coronary arteries is constant, then volume flow is related to the total cross-sectional area of these vessels. There were no patients with a disproportionate increase in wall mass caused by important aortic stenosis in this study, and only a few patients had a high left ventricular end-diastolic pressure. In addition, this study provides no information about the complex interrelation between the pressure gradient across 


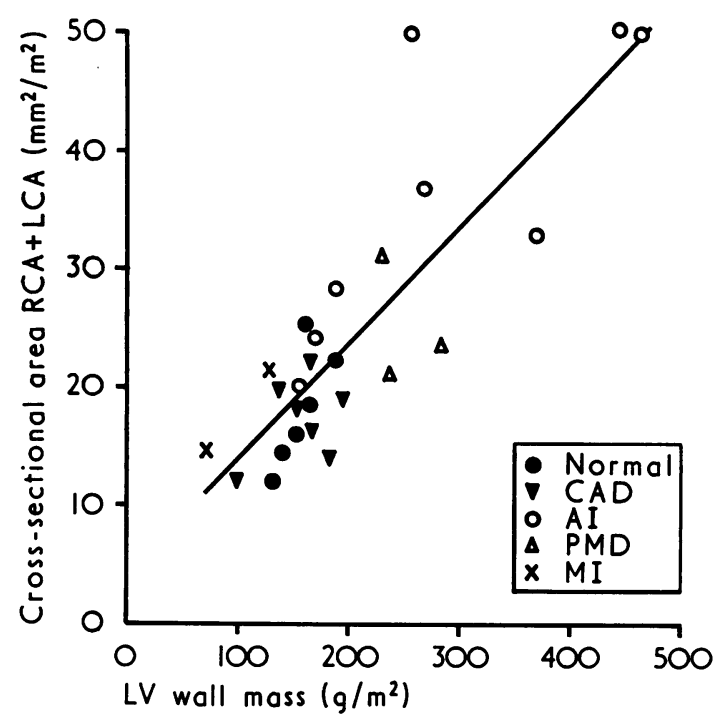

FIG. I Linear relation between total luminal crosssectional area of proximal coronary arteries $(R C A+$ $L C A$ ) and left ventricular wall mass (cross-sectional area $=0.10 \mathrm{LV}$ wall mass $+4.58 ; r=0.84, P<0.001)$.

the coronary vascular bed, the velocity of blood flow, and the diameter and length of the coronary vessels. The velocity of coronary flow and absolute coronary blood flow were not measured.

The close linear relation between coronary artery size and left ventricular wall mass suggests that the

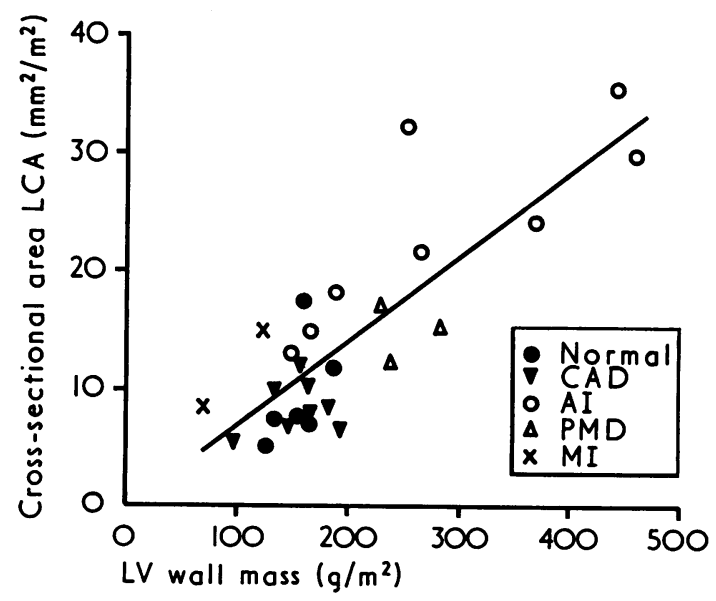

FIG. 2 Linear relation between luminal crosssectional area of left coronary artery $(L C A)$ and left ventricular wall mass (cross-sectional area $=0.07 \mathrm{LV}$ wall mass-0.06; $r=0.82, P<0.001)$.

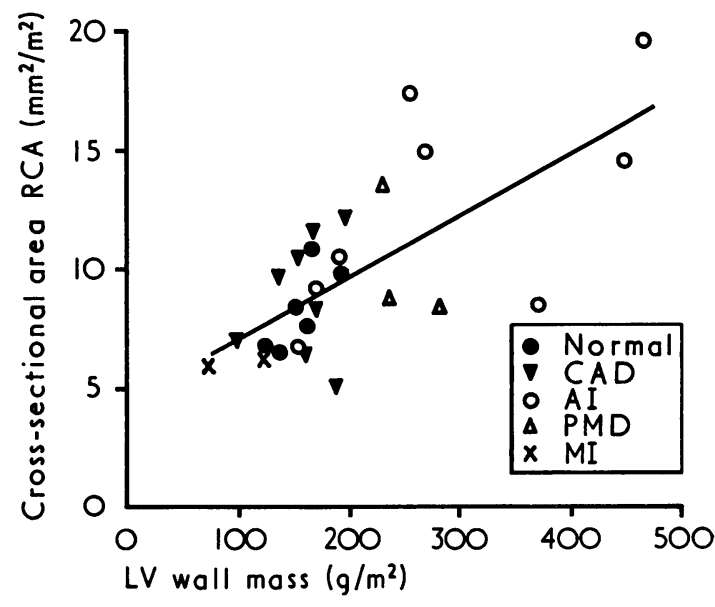

FIG. 3 Linear relation between luminal crosssectional area of right coronary artery $(R C A)$ and left ventricular wall mass (cross-sectional area $=0.03$ $L V$ wall mass $+4.62 ; r=0.68, P<0.001)$.

increase in absolute blood flow in myocardial hypertrophy is accommodated by dilatation of the coronary arteries, and the degree of dilatation is in keeping with the degree of ventricular hypertrophy. We have shown that a similar relation exists in most patients with primary myocardial disease, but, in a few, left ventricular wall mass exceeds the increase in coronary size. In these circumstances, part of the increase in wall mass may be due to an increase in fibrous tissue and/or inter- and intracellular oedema (Lewis and Gotsman, 1973).

Increase in cross-sectional area of the coronary arteries was mainly a consequence of increase in size of the left coronary artery, but the smaller, similar increase in size of the right coronary artery was not unexpected as the posterior interventricular artery and the ventricular branches of the distal right coronary artery perfuse the posterior part of the interventricular septum and the posterior and diaphragmatic surfaces of the left ventricle. Moreover, conditions that cause left ventricular hypertrophy are often associated with pulmonary venous and arterial hypertension, producing minor additional right ventricular hypertrophy. No patient in this group had important mitral valve disease and pulmonary arterial hypertension which could produce enlargement of the right coronary artery without an increase in left ventricular muscle mass.

\section{References}

Braunwald, E. (1971). Control of myocardial oxygen consumption. Physiologic and clinical considerations. American fournal of Cardiology, 27, 416. 
Brink, A. J., and Lewis, C. M. (1967). Coronary blood flow, energetics, and myocardial metabolism in idiopathic mural endomyocardiopathy (I4 patients). American Heart Fournal, 73, 339.

Britman, N. A., and Levine, H. J. (1964). Contractile element work: a major determinant of myocardial oxygen consumption. Fournal of Clinical Investigation, 43, 1397.

Coleman, H. N. (197I). Determinants of myocardial energy utilization. In Cardiac Hypertrophy, p. 485. Ed. by N. R. Alpert. Academic Press, New York.

Frank, M. J., Levinson, G. E., and Hellems, H. K. (I965). Left ventricular oxygen consumption, blood flow, and performance in mitral stenosis. Circulation, 31, 824.

Gorlin, R., Cohen, L. S., Elliott, W. C., Klein, M. D., and Lane, F. J. (1964). Haemodynamics of muscular subaortic stenosis (obstructive cardiomyopathy). In Ciba Foundation Symposium: Cardiomyopathies, p. 76. Ed. by G. E. W. Wolstenholme and M. O'Connor. Churchill, London.

Gotsman, M. S., Bakst, A., Lewis, B. S., Mitha, A. S., and Reznik, M. L. (1973). Technical aspects of coronary angiography. South African Medical Fournal, 43, 1037.

Gotsman, M. S., Winship, W. S., Quantrill, J. R., and van der Horst, R. L. (1969). Diagnostic selective coronary arteriography. South African Medical fournal, 43, II4I.

Greene, D. G., Carlisle, R., Grant, C., and Bunnell, I. L. (1967). Estimation of left ventricular volume by oneplane cineangiography. Circulation, 35, 6r.

Holmberg, S., Paulin, S., Prerovsky, I., and Varnauskas, E. (1967). Coronary blood flow in man and its relation to the coronary arteriogram. American fournal of Cardiology, 19, 486.

Hood, W. P. (197I). Dynamics of hypertrophy in the left ventricular wall of man. In Cardiac Hypertrophy, p. 445. Ed. by N. R. Alpert. Academic Press, New York.

Judkins, M. P. (1967). Selective coronary arteriography. A percutaneous transfemoral technic. Radiology, 89, 815.

Kennedy, J. W., Trenholme, S. E., and Kasser, I. S. (1970).
Left ventricular volume and mass from single-plane cineangiocardiogram. A comparison of anteroposterior and right anterior oblique methods. American Heart fournal, 80, 343.

Lewis, B. S., and Gotsman, M. S. (1973). Selective coronary angiography in primary myocardial disease. British Heart Fournal, 35, 165 .

MacAlpin, R. N., Abassi, A. S., Grollman, J. H., and Eber, L. (1972). Human coronary artery size during life. Circulation, 45-46, Suppl., II-6.

Rackley, C. E., Hood, W. P., Rolett, E. L., and Young, D. T. (1970). Left ventricular end-diastolic pressure in chronic heart disease. American fournal of Medicine, 48, 310.

Rees, G. M. (1972). Derivation of magnification factor from the image of the cardiac catheter. British fournal of Radiology, 45, 624 .

Ross, R. S., Ueda, K., Lichtlen, P. R., and Rees, J. R. (1964). Measurement of myocardial blood flow in animals and man by selective injection of radioactive inert gas into the coronary arteries. Circulation Research, 15, 28.

Rowe, G. G., Afonso, S., Lugo, J. E., Castillo, C. A., Boake, W. C., and Crumpton, C. W. (1965). Coronary blood flow and myocardial oxidative metabolism at rest and during exercise in subjects with severe aortic valve disease. Circulation, 32, 25I.

Sarnoff, S. J., Braunwald, E., Welch, G. H., Case, R. B., Stainsby, W. N., and Macruz, R. (1958). Hemodynamic determinants of oxygen consumption of the heart, with special reference to the tension-time index. American Fournal of Physiology, 192, r48.

Sonnenblick, E. H., and Skelton, C. L. (1971). Oxygen consumption of the heart: physiological principles and clinical implications. Modern Concepts of Cardiovascular Disease, 40, 9.

Requests for reprints to Professor M. S. Gotsman, Cardiac Unit, Wentworth Hospital, P. B. Jacobs, Natal, South Africa. 